\title{
Measurement of Gas Diffusion Capacity of Cigarette Papers*
}

\author{
by \\ Alan B. Norman, Jason C. Caudle, and Calvin W. Henderson \\ R. J. Reynolds Tobacco Company, P.O. Box 1487, Winston-Salem, NC 27102-1487, USA
}

\section{SUMMARY}

Apparatus suitable for measuring gas diffusion capacity of cigarette paper was assembled and evaluated. The apparatus provides semi-automated means for measuring the concentration of carbon dioxide diffusing through a small area of the paper, and computation of a paper thickness-dependent diffusion capacity of the sample. Measurements are rapid and can be made in about $30 \mathrm{~s}$. Diffusion capacity measurements were repeatable and reproducible to within about $1 \%$. Variability of the diffusion capacity values was much lower than that observed for permeability measurements. For these reasons, the apparatus is useful for quality assessment and research applications. Diffusion capacity was measured for cigarette papers of inherent permeability ranging from 6 to $62 \mathrm{~cm} / \mathrm{min}$. As expected from prevailing theory, the diffusion capacity values generally increased with permeability. The diffusion capacity measured for electrostatically perforated papers was only slightly higher (about 6-11\%) than the unperforated base paper despite large increases in permeability. This result indicates that diffusion capacity is governed by small pores in the paper. The apparatus is capable of measuring banded areas of papers designed for reduced ignition propensity. Diffusion capacity values for banded areas were lower than those of non-banded paper of similar permeability, suggesting that the band material preferentially occludes small pores in the paper. [Beitr. Tabakforsch. Int. 21 (2005) 425-434]

\section{ZUSAMMENFASSUNG}

Ein Gerät zur Messung der Diffusionseigenschaften des Zigarettenpapiers für Gase wurde entwickelt und evaluiert. Das Gerät enthält eine halbautomatische Vorrichtung zur Messung der Kohlendioxiddiffusion durch einen kleinen Papierbereich und zur Berechnung der von der Papierdicke abhängigen Diffusionsfähigkeit der Probe. Die Messungen erfolgen schnell in ungefähr 30 Sekunden. Die Wiederholbarkeit und Reproduzierbarkeit für die Messungen der Diffusionsfähigkeit betrug ca. 1\%. Die Schwankungsbreite der Werte war für die Messung der Diffusionsfähigkeit wesentlich niedriger als für die Permeabilität. Aus diesem Grund ist die Vorrichtung zur Qualitätsbestimmung und für Forschungsanwendungen geeignet. Die Diffusionsfähigkeit wurde bei Zigarettenpapier mit einer inhärenten Permeabilität von 6 bis $62 \mathrm{~cm} / \mathrm{min}$ gemessen. Wie aus der gängigen Theorie zu erwarten war, nahm die Diffusionsfähigkeit mit der Permeabilität zu. Die bei elektrostatisch perforiertem Zigarettenpapier gemessene Diffusionsfähigkeit war trotz starker Zunahme der Permeabilität nur wenig höher (ungefähr 6-11\%) als bei unperforiertem Papier. Dieses Ergebnis deutet darauf hin, dass die Diffusionsfähigkeit von kleinen Poren im Papier bestimmt wird. Mithilfe des Gerätes lassen sich Bandbereiche des Papiers messen, die für eine verringerte Entflammbarkeit entwickelt wurden. Die Diffusionskapazität dieser Bandbereiche war niedriger als bei Papier ohne solche Bereiche gleicher Permeabilität, was darauf hindeutet, dass das für die Bänderung verwendete Material kleine Poren im Papier abdeckt. [Beitr. Tabakforsch. Int. 21 (2005) 425-434]

\section{RESUME}

Un dispositif pour mesurer la capacité de diffusion de gaz du papier à cigarette a été conçu et évalué. Cet appareil permet de mesurer de façon semi-automatique la concentration de dioxyde de carbone diffusant à travers une petite partie du papier, et le calcul de la capacité de diffusion de l'échantillon en fonction de l'épaisseur du papier. Les mesures sont rapides et peuvent être faites en 30 secondes environ. La mesure de la capacité de diffusion est répétable et reproductible d'environ $1 \%$. La variabilité de la capacité de diffusion est beaucoup plus réduite que celle de la perméabilité. Pour ces raisons, l'appareil est utile pour 
l'évaluation de la qualité et pour des applications scientifiques. La capacité de diffusion a été mesurée pour des papiers à cigarette d'une perméabilité inhérente de 6 à 62 $\mathrm{cm} / \mathrm{min}$. Comme il était à prévoir selon la théorie prévalente, les valeurs de la capacité de diffusion augmentent en fonction de la perméabilité. La capacité de diffusion mesurée pour des papiers perforés de façon électrostatique est seulement légèrement plus élevée que celle du papier non perforé, malgré une forte augmentation de la perméabilité. Ce résultat indique que la capacité de diffusion est déterminée par des petits pores dans le papier. L'appareil est capable de mesurer les parties bandées du papier conçues pour réduire la propension à l'ignition. Les valeurs de la capacité de diffusion mesurées pour les parties bandées sont plus basses que celles de papiers non bandées ayant une perméabilité identique, suggérant que le matériel des bandes couvre surtout les petits pores du papier. [Beitr. Tabakforsch. Int. 21 (2005) 424-434]

\section{INTRODUCTION}

Cigarette papers are routinely characterized by permeability, which is defined as the flow rate through a specified area of paper at a specified pressure differential across the sample. With all other parameters constant, cigarette smolder rates increase with increasing inherent permeability of the paper. However, perforation of paper to increase the permeability does not produce commensurate cigarette burn rate elevation. Additionally, burn rate differences have been demonstrated for papers of equivalent inherent permeability but varying filler and fiber contents. In this case, the burn rate differences appear related to the pore size distribution in the paper (1). These observations suggest that cigarette burn rates are not governed exclusively by paper permeability. It appears more likely that cigarette burn rates are moderated by the extent of oxygen diffusion through the paper during smolder.

Recently, considerable effort has been devoted to development of papers that enable cigarettes to meet a selfextinction standard imposed by the state of New York (2). The New York State regulation requires that cigarettes sold there show a self-extinction rate of at least $75 \%$ as measured by a standard test procedure (3). Typical papers developed for this purpose are intermittently printed with bands of materials that reduce the paper permeability. As band permeability decreases, the within-band burn rates decrease and self-extinction rates increase. For a given band material, band permeability provides a fairly good indication of self-extinction performance (4). To date, band permeability has been used as a specification for determining fitness of papers for meeting the New York State regulatory standard. Band permeability measurement is difficult because of the small band area (typically $6 \mathrm{~mm}$ width) and attendant low flow rate through the band (functional band permeability can range from less than 2 $\mathrm{cm} / \mathrm{min}$ to about $15 \mathrm{~cm} / \mathrm{min}$ ). Permeability measurements are subject to error from leakage around the seals between the sample and the sample clamp. Small leakage can cause large relative errors in band permeability measurements because the flow rates of interest are very low (5). Pinholes within the banded area can also result in large relative errors. As a result of these and other potential measurement errors, band permeability data tend to be highly variable.

Porous cigarette papers have been shown to permit diffusion of low molecular weight gases. The extent of diffusion of carbon monoxide and other gases through the paper in tobacco rods has been documented (6,7). Direct measurement of gas diffusion coefficients through cigarette paper has been reported using carbon monoxide $(6,8)$ and oxygen $(9)$ as the diffusing gases. An indirect measurement method (termed Burn Mode Index; BMI or Diffusional Conductance Index; DCI) for determining the relative potential for gas diffusion in cigarette paper has also been reported (10). The DCI measurement of cigarette paper is reportedly a direct indication of the cigarette static burn rate. Recently, EITZINGER (11) developed a theoretical model suggesting that low diffusion coefficients are required for high self-extinction rates in print-banded papers. The diffusion coefficient measurement procedure described by DRAKE (8) requires zero pressure differential across the paper sample. Because of this, leakage around the sample holder should be minimized. BAKER (6) reported that perforations in the paper (and by extension, pinholes) had minimal influence on measured diffusion coefficients. Thus, measurement of gas diffusion through paper could represent an alternative that resolves some of the problems with permeability noted above.

An instrument for making direct measurements of gas diffusion coefficients through papers is not commercially available. Therefore, a suitable rapid-measurement apparatus was designed and built. Only a few diffusion coefficients for cigarette paper $(6,9)$, and none for banded paper, have been reported in the literature. The diffusion apparatus was used to characterize unprinted conventional, perforated, and banded papers to gain insight on the potential use of diffusion coefficients for paper specification.

\section{EXPERIMENTAL}

The apparatus used for measuring gas diffusion through cigarette paper is similar to that described by DRAKE (8). A block diagram indicating major components of the apparatus is shown in Figure 1. The diffusion cell is custom fabricated and comprises identical upper and lower flow chambers. Each chamber includes a slot $(0.4 \mathrm{~cm}$ wide, $2.0 \mathrm{~cm}$ long and $0.1 \mathrm{~cm}$ deep) that defines the paper area through which gas diffusion is measured. Tapered tubes machined into the chambers connect each end of the slots to fittings for gas inlets and outlets. Fittings are placed in the centers of the upper and lower slots for connection of a differential pressure transducer (Custom Electronics Systems, Rural Hall, NC, model CES-467) to monitor the pressure differential between the flow chambers. The sample-contact surfaces of the upper and lower chambers are machined flat. No gaskets or sealing materials are needed to prevent leakage around the test sample. The upper flow chamber of the diffusion cell is depicted in Figure 2. The lower cell chamber is mounted in a fixed position on a metal backing plate while the upper chamber is mounted on a pneumatic device which lifts the upper chamber to permit positioning of the paper sample between the chambers. The pneumatic device is actuated with a foot switch to open and close the cell. 


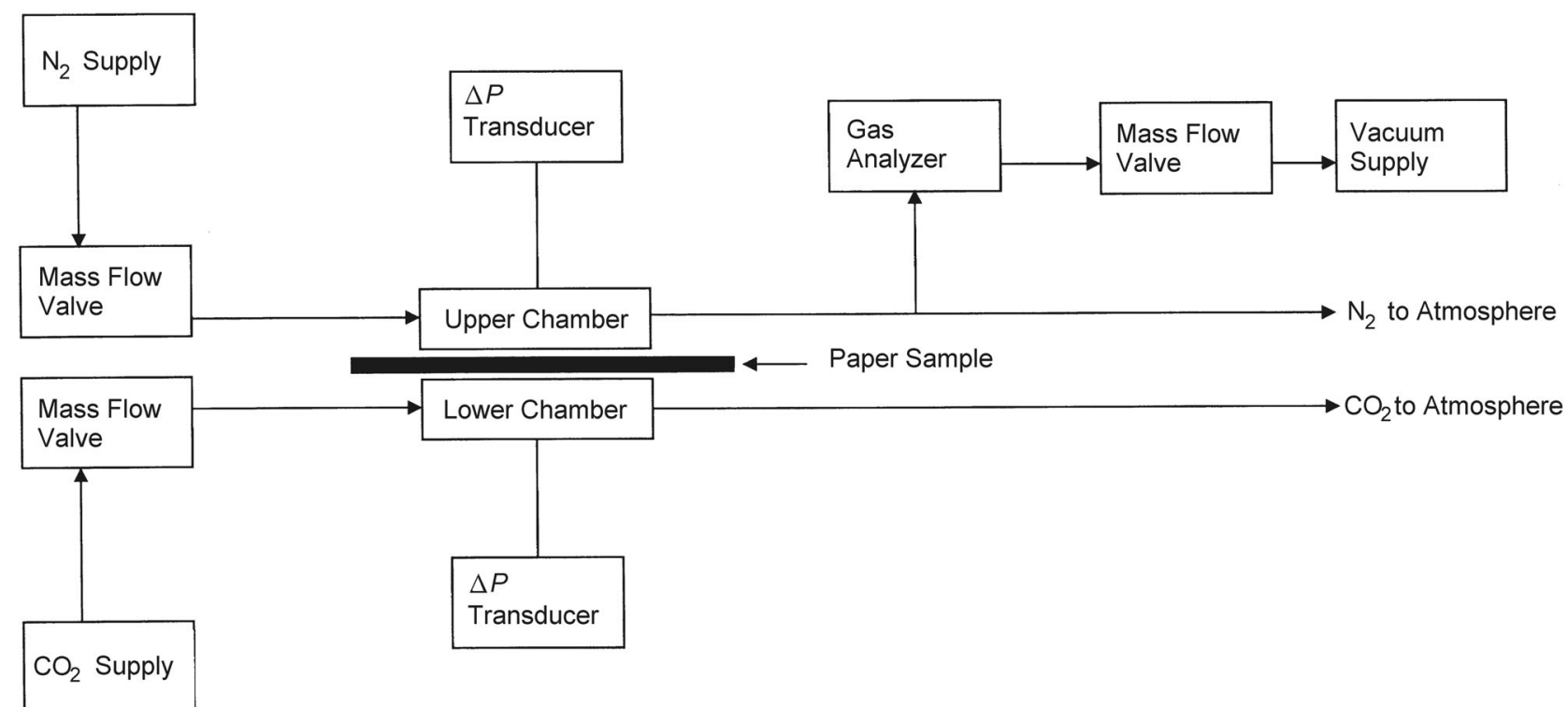

Figure 1. Block diagram of diffusion measurement apparatus

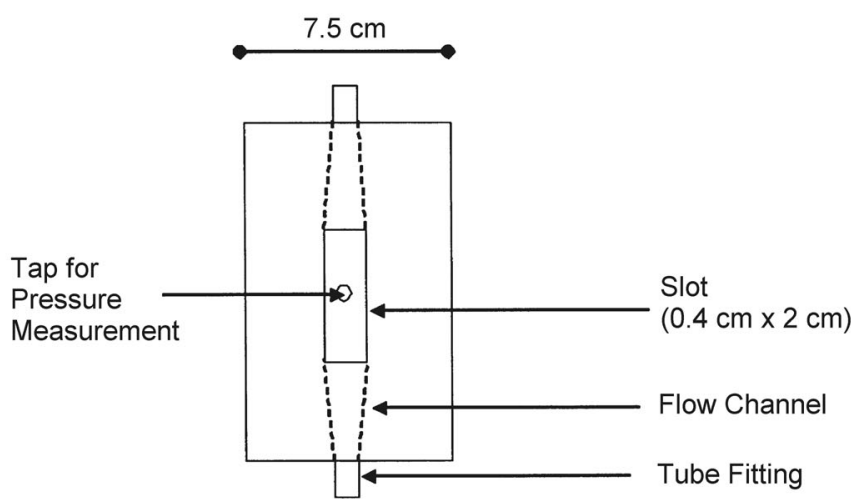

Top View of Flow Chamber

Figure 2. Diffusion cell upper flow chamber

Carbon dioxide (100\%) was chosen as the marker gas, instead of a CO/ $\mathrm{N}_{2}$ mixture as described by DRAKE (8), to maximize concentration readings and to provide for laboratory safety. The $\mathrm{CO}_{2}$ supply is metered to the inlet of the lower flow chamber of the diffusion cell through a mass flow control valve (Brooks Instrument, Hatfield, PA, model 5850E, 0 to 1 Standard Liter Per Minute; SLPM, range) set to deliver 500 Standard Cubic Centimeters Per Minute (SCCM; $\mathrm{cm}^{3} / \mathrm{min}$ at $760 \mathrm{mmHg}$ and $273^{\circ} \mathrm{K}$ ). The $\mathrm{N}_{2}$ carrier gas supply is metered to the inlet of the upper flow chamber through a mass flow control valve (Brooks Instrument $5850 \mathrm{E}, 0$ to 1 SLPM) also set to deliver 500 SCCM. The outlet from the upper flow chamber is connected to a " $T$ " fitting, one end of which is open to the atmosphere and the other end connected to the inlet of a $\mathrm{CO}_{2}$ analyzer (Rosemount Analytical, Orrville, $\mathrm{OH}$, model NGA 2000, 0 to $20 \%$ range). The outlet of the gas analyzer was connected to a vacuum source metered through a mass flow control valve (Brooks Instrument 5850E, 0 to 1 SLPM) set to provide 200 SCCM gas flow through the analyzer. This sample loop connection minimizes the pres- sure differential between the upper chamber and atmosphere. (Preliminary experiments during which the upper chamber outlet was directly connected to the analyzer inlet compressed the range of $\mathrm{CO}_{2}$ concentration readings observed for papers of widely varying permeability. After changing to the sample loop arrangement, a much wider range of $\mathrm{CO}_{2}$ concentrations was found for tests of the same papers. It was concluded from these observations that the sample loop is necessary to avoid false results.) Flexible tubing is connected to the outlet from the lower flow chamber. The length of this tube is adjusted to obtain essentially zero $\left( \pm 0.2 \mathrm{mmH}_{2} \mathrm{O}\right)$ pressure differential between the upper and lower chambers. This adjustment is made with an impermeable plastic film clamped between the chambers, and with the $\mathrm{CO}_{2}, \mathrm{~N}_{2}$ and vacuum flow rates set as described. Once set, the cell pressure differential is very stable and requires adjustment only if a substantially different flow rate is used.

Barometric pressure (Vaisala Oyj, Vantaa, Finland, barometric pressure transmitter, model PTB-100A) and ambient temperature (Custom Electronics Systems CES-467) 
are recorded during each diffusion measurement and are used in the ideal gas equation to calculate the flow through the diffusion cell. The flow rate at ambient conditions is used in the calculation of the diffusion capacity. Also, barometric pressure compensation is applied to the $\mathrm{CO}_{2}$ concentration measurements.

The diffusion measurement apparatus is interfaced with a computer (IBM, White Plains, NY, model Net Vista) using custom-developed software to provide partial automation of the measurement and calibration procedures. The computer is equipped with National Instruments (Austin, TX) analog input (PCI-6034E) and analog output (PCI-6703) devices. During sample measurements, the computer monitors the analog output from the $\mathrm{CO}_{2}$ analyzer to determine concentration stability (concentration stability is reached after about $15 \mathrm{~s}$ ). After the $\mathrm{CO}_{2}$ concentration is stable, barometric pressure and ambient temperature readings are obtained, and the diffusion capacity is calculated, displayed and logged to a data file. The computer also monitors the differential pressure across the sample, and the analog voltages from the flow control valves. The computer displays error messages if the differential pressure value is outside the tolerance range $\left( \pm 1.0 \mathrm{mmH}_{2} \mathrm{O}\right)$ or if there is no gas flow from one or more of the valves. Facilities were included in the custom computer software to calibrate the flow control valves and the $\mathrm{CO}_{2}$ analyzer. In the valve calibration mode, two voltages are applied to each valve and the flow rate is measured (Bios International, Butler, NJ, Dry-Cal DC-2 Flow Calibrator) for each voltage. The control voltage required for the target flow rate is calculated from these data. The $\mathrm{CO}_{2}$ analyzer is zeroed with nitrogen flowing through the system at 200 SCCM. The span is calibrated with $18.5 \% \mathrm{CO}_{2}$ in nitrogen flowing through the system at 200 SCCM. Long-term testing indicated that weekly analyzer calibration is necessary for best results. Valve calibration is required less frequently (monthly or bi-monthly).

The gas diffusion coefficient through paper (units are $\mathrm{cm}^{2} / \mathrm{s}$ ) is an intrinsic property of the material that is independent of the paper thickness. Since the diffusive property of the paper is probably more relevant to cigarette performance than that of the material, results are expressed as a thickness-dependent quantity, denoted "diffusion capacity" or $D^{*}$ (units are $\mathrm{cm} / \mathrm{s}$ ). Note that the standard paper permeability measure is also thickness-dependent. Paper diffusion capacity can be calculated using the mathematical model described by DRAKE (8). This model requires as input the flow rate, cell dimensions, binary diffusion coefficient of $\mathrm{CO}_{2}$ into $\mathrm{N}_{2}$, and the gas concentration measured in the $\mathrm{N}_{2}$ stream with a paper sample in place. Because this model requires numerical evaluation, a computer program was written to adjust the diffusion coefficient until the calculated concentration of the diffusing gas in the carrier gas stream matched the measured value to within $0.01 \%$. In some cases, the Drake model did not converge to the measured diffusing gas concentration value due to local undefined regions resulting from the tangent function employed in this solution. To avoid the convergence problems with the Drake model, a regression model was developed and used to calculate the diffusion coefficients from the measured diffusing gas concentration data. The regression model was developed by cal- culating diffusion coefficients with the Drake model for a wide range of diffusing gas concentrations, using an inlet flow rate of $574 \mathrm{~mL} / \mathrm{min}$ and the diffusion cell dimensions described above. A $4^{\text {th }}$ order polynomial was used to fit the gas concentrations to the diffusion coefficient results. Reported diffusion capacity values were calculated from the polynomial fit and normalized to the ambient volumetric flow rate (that is, the normalized result is the value from the regression equation multiplied by the volumetric flow divided by the flow rate used to develop the regression model). Note that the polynomial regression is specific to one set of cell dimensions with $\mathrm{CO}_{2}$ as the diffusing gas. The value for the binary diffusion coefficient for $\mathrm{CO}_{2}$ into $\mathrm{N}_{2}\left(0.17 \mathrm{~cm}^{2} / \mathrm{s}\right)$ was obtained from published data (12).

Conventional cigarette papers tested ranged from 6 to 62 $\mathrm{cm} / \mathrm{min}$ permeability, and were obtained from two suppliers. An additional conventional paper of $40 \mathrm{~cm} / \mathrm{min}$ permeability was electrostatically perforated to about 80,150 and $240 \mathrm{~cm} / \mathrm{min}$ permeability. Papers with printed bands of a range of permeability values were produced by varying the amount of band material applied to the paper in a gravure printing process. The band material was primarily starch, and the bands were $6 \mathrm{~mm}$ in width, spaced $19 \mathrm{~mm}$ apart. Millipore filters with nominal pore diameters of $0.025 \mu \mathrm{m}$ (catalog number VSWP09025), $0.1 \mu \mathrm{m}$ (VCWP09025), $0.3 \mu \mathrm{m}$ (PHWP09025), and $0.65 \mu \mathrm{m}$ (DAWP09025) were obtained from Fisher Scientific (Hampton, NH). Permeability measurements were made with a Borgwaldt (Hamburg, Germany) A10 instrument using a $2 \mathrm{~cm}^{2}$ opening for conventional papers, and a $2 \mathrm{~mm}$ by $15 \mathrm{~mm}$ opening for banded areas. All paper tests were conducted in a laboratory with controlled temperature $\left(24{ }^{\circ} \mathrm{C}\right)$ and humidity $(60 \% \mathrm{RH})$ conditions. Paper samples were stored in the laboratory for at least $72 \mathrm{~h}$ prior to testing.

\section{RESULTS AND DISCUSSION}

\section{Evaluation of instrument performance}

Repeatability of the diffusion capacity measurements was determined by making ten replicate readings of the same, marked area of a cigarette paper strip. The paper strip was marked with a pencil line that was subsequently aligned with the left-most edge of the diffusion cell slot so that the mark was not included in the measurement area. Replicate repeatability determinations were made on five test days for papers of low $(5 \mathrm{~cm} / \mathrm{min})$ and high $(50 \mathrm{~cm} / \mathrm{min})$ permeability. No alterations to the analyzer or flow valve calibrations were made during these experiments. The results are summarized in Table 1. For the low permeability paper, the daily average diffusion capacity ranged from 0.331 to $0.334 \mathrm{~cm} / \mathrm{s}$, and the coefficient of variation $(\mathrm{COV})$ ranged from 0.5 to $0.7 \%$. The average diffusion capacity found for the high permeability paper ranged from 1.549 to 1.585 $\mathrm{cm} / \mathrm{s}$, and the COV ranged from 0.2 to $0.7 \%$. On average, the repeatability for the low $(\mathrm{COV}=0.6 \%)$ and high $(\mathrm{COV}$ $=0.4 \%$ ) permeability papers was quite good. The results for the high permeability paper showed day-to-day variance in the diffusion capacity results $(\mathrm{COV}=0.9 \%)$ that is larger than the average within-day variability. 
Table 1. Repeatability of diffusion capacity measurements for papers of low and high permeability

\begin{tabular}{l|c|c|c|c|c|c}
\hline \multirow{2}{*}{ Test day } & \multicolumn{3}{c}{ Low permeability paper $D^{*}$} & \multicolumn{3}{c}{ High permeability paper $D^{*}$} \\
\cline { 2 - 7 } & $\begin{array}{c}\text { Average } \\
(\mathrm{cm} / \mathrm{s})\end{array}$ & $\begin{array}{c}\mathrm{SD}^{\mathrm{a}} \\
(\mathrm{cm} / \mathrm{s})\end{array}$ & $\begin{array}{c}\mathrm{COV}^{\mathrm{a}} \\
(\%)\end{array}$ & $\begin{array}{c}\text { Average } \\
(\mathrm{cm} / \mathrm{s})\end{array}$ & $\begin{array}{c}\mathrm{SD}^{\mathrm{a}} \\
(\mathrm{cm} / \mathrm{s})\end{array}$ & $\begin{array}{c}\mathrm{COV}^{\mathrm{a}} \\
(\%)\end{array}$ \\
\hline 1 & 0.332 & 0.002 & 0.7 & 1.566 & 0.003 & 0.2 \\
3 & 0.331 & 0.002 & 0.6 & 1.584 & 0.006 & 0.4 \\
4 & 0.333 & 0.002 & 0.5 & 1.549 & 0.011 & 0.7 \\
5 & 0.333 & 0.002 & 0.7 & 1.585 & 0.007 & 0.5 \\
Average $^{\mathrm{b}}$ & 0.334 & 0.002 & 0.5 & 1.570 & 0.007 & 0.5 \\
SD $^{c}$ & 0.332 & 0.002 & 0.6 & 1.571 & 0.007 & 0.4 \\
COV $^{c}$ & 0.001 & & & 0.015 & & \\
\hline
\end{tabular}

${ }^{a}$ Average, standard deviation (SD) and coefficient of variation (COV) for ten measurements of the same paper area.

${ }^{\mathrm{b}}$ Averages of the daily values.

${ }^{\circ} \mathrm{SD}$ and COV of the daily average diffusion capacity.

Table 2. Reproducibility of diffusion capacity measurements for papers of low and high permeability

\begin{tabular}{l|c|c|c|c|c|c}
\hline \multirow{2}{*}{ Test day } & \multicolumn{3}{|c|}{ Low permeability paper $D^{*}$} & \multicolumn{3}{c}{ High permeability paper $D^{*}$} \\
\cline { 2 - 7 } & $\begin{array}{c}\text { Average } \\
(\mathrm{cm} / \mathrm{s})\end{array}$ & $\begin{array}{c}\mathrm{SD}^{\mathrm{a}} \\
(\mathrm{cm} / \mathrm{s})\end{array}$ & $\begin{array}{c}\mathrm{COV}^{\mathrm{a}} \\
(\%)\end{array}$ & $\begin{array}{c}\text { Average }^{\mathrm{a}} \\
(\mathrm{cm} / \mathrm{s})\end{array}$ & $\begin{array}{c}\mathrm{SD}^{\mathrm{a}} \\
(\mathrm{cm} / \mathrm{s})\end{array}$ & $\begin{array}{c}\mathrm{COV}^{\mathrm{a}} \\
(\%)\end{array}$ \\
\hline 1 & 0.326 & 0.011 & 3.5 & 1.503 & 0.061 & 4.0 \\
2 & 0.326 & 0.011 & 3.3 & 1.523 & 0.064 & 4.2 \\
3 & 0.326 & 0.012 & 3.7 & 1.502 & 0.055 & 3.6 \\
4 & 0.327 & 0.012 & 3.7 & 1.517 & 0.052 & 3.5 \\
5 & 0.327 & 0.014 & 4.2 & 1.506 & 0.064 & 4.3 \\
Average $^{\mathrm{b}}$ & 0.326 & 0.012 & 3.7 & 1.510 & 0.059 & 3.9 \\
SD $^{\mathrm{c}}$ & 0.001 & & & 0.009 & & \\
COV $^{c}$ & 0.2 & & & 0.6 & & \\
\hline
\end{tabular}

${ }^{\text {a } A v e r a g e, ~(S D) ~ s t a n d a r d ~ d e v i a t i o n ~ a n d ~ c o e f f i c i e n t ~ o f ~ v a r i a t i o n ~(C O V) ~ f o r ~ f i v e ~ m e a s u r e m e n t s ~ o f ~ d i f f e r e n t ~ p a p e r ~ a r e a s . ~}$

${ }^{\mathrm{b}}$ Averages of the daily values.

${ }^{\mathrm{c}} \mathrm{SD}$ and COV of the daily average diffusion capacity.

Table 3. Long-term reproducibility of diffusion capacity measurements for filter membranes

\begin{tabular}{l|c|c}
\hline Pore diameter $^{\mathrm{a}}(\mu \mathrm{m})$ & $\begin{array}{c}\text { Average } D^{\star \mathrm{b}} \\
(\mathrm{cm} / \mathrm{s})\end{array}$ & $\begin{array}{c}\mathrm{COV}^{\mathrm{b}} \\
(\%)\end{array}$ \\
\hline 0.025 & 1.364 & 1.0 \\
0.1 & 2.048 & 1.2 \\
0.65 & 3.288 & 1.7 \\
\hline
\end{tabular}

${ }^{a}$ Specified maximum pore diameter for Milliporefilter membrane.

${ }^{\mathrm{b}}$ Average diffusion capacity for 79 measurements of the same filter membrane.

Reproducibility of the diffusion capacity measurements was determined by making readings of five different, marked (as described above) areas of a cigarette paper strip. Replicate reproducibility determinations were made on five test days for papers of low $(5 \mathrm{~cm} / \mathrm{min})$ and high $(50$ $\mathrm{cm} / \mathrm{min}$ ) permeability. The same marked areas on the paper strips were measured for each determination. The results are summarized in Table 2. The average diffusion capacity found for the low permeability ranged from 0.326 to $0.327 \mathrm{~cm} / \mathrm{s}$, and the COV ranged from 3.3 to $4.2 \%$. For the high permeability paper, the average diffusion capacity ranged from 1.502 to $1.523 \mathrm{~cm} / \mathrm{s}$, and the $\mathrm{COV}$ ranged from 3.5 to $4.3 \%$. Diffusion capacity COV for the five test days averaged $0.2 \%$ for the low permeability paper, and $0.6 \%$ for the high permeability paper. Thus, the repeatability and the reproducibility measures were about the same magnitude, and much less than the variability within the paper strips tested.

A set of Millipore filter membranes is routinely tested as a check for consistency of the diffusion capacity instrument. Average diffusion capacity and COV values from 79 tests of the filter membranes made over a five month period are shown in Table 3. Variability increased with the diffusion capacity value from $1 \%$ at $1.364 \mathrm{~cm} / \mathrm{s}$ to $1.7 \%$ at 3.288 $\mathrm{cm} / \mathrm{s}$. However, none of the cigarette papers tested to date showed a diffusion capacity value above about $2 \mathrm{~cm} / \mathrm{s}$. Thus, the results in Table 3 suggest that a worst-case estimate for long-term variability of cigarette paper diffusion capacity would be about $1.2 \%$.

No diffusion standard appropriate for assessing the absolute accuracy of the diffusion capacity values could be found. However, pore size estimates made from permeability and diffusion capacity measurements were compared to values specified for a series of Millipore filter membranes in an attempt to verify the accuracy of the diffusion capacity measurements. Pore sizes of the filter membranes were 
Table 4. Pore radius estimates for filter membranes

\begin{tabular}{l|c|c|c|c|c}
\hline Pore radius $^{\mathrm{a}}(\mu \mathrm{m})$ & $\begin{array}{c}\text { Thickness } \\
(\mu \mathrm{m})\end{array}$ & $\begin{array}{c}\text { Permeability } \\
(\mathrm{cm} / \mathrm{min})\end{array}$ & $\begin{array}{c}D^{*} \\
(\mathrm{~cm} / \mathrm{s})\end{array}$ & $\begin{array}{c}D_{\mathrm{p}}^{\mathrm{c}} \\
\left(\mathrm{cm}^{2} / \mathrm{s}\right)\end{array}$ & $\begin{array}{c}\text { Estimated } \\
\text { pore radius }\end{array}$ \\
\hline 0.013 & 85 & 2.7 & 1.373 & $1.17 \mathrm{E}-02$ & 0.29 \\
0.050 & 85 & 5.6 & 2.052 & $1.74 \mathrm{E}-02$ & 0.34 \\
0.150 & 150 & 42.0 & 2.686 & $4.03 \mathrm{E}-02$ & 0.82 \\
0.325 & 150 & 176.5 & 3.261 & $4.89 \mathrm{E}-02$ & 1.52 \\
\hline
\end{tabular}

${ }^{a}$ Specified maximum pore radius for Millipore filter membrane.

${ }^{b}$ Permeability measured according to CORESTA standards.

${ }^{c} D_{\mathrm{p}}=D^{*}$ multiplied by the membrane thickness in $\mathrm{cm}$.

${ }^{\mathrm{d}}$ Estimated from experimental values for $D^{\star}$ and permeability using Eqn. [4].

Table 5. Effect of cell differential pressure on diffusion capacity measurements for papers of low and high permeability

\begin{tabular}{|c|c|c|c|c|c|c|}
\hline \multirow[b]{2}{*}{$\begin{array}{l}\text { Cell } \Delta P^{\mathrm{a}} \\
\left(\mathrm{mmH}_{2} \mathrm{O}\right)\end{array}$} & \multicolumn{3}{|c|}{ Low permeability paper $D^{*}$} & \multicolumn{3}{|c|}{ High permeability paper $D^{\star}$} \\
\hline & $\begin{array}{l}\text { Average }^{b} \\
(\mathrm{~cm} / \mathrm{s})\end{array}$ & $\begin{array}{c}\mathrm{COV}^{\mathrm{b}} \\
(\%)\end{array}$ & $\begin{array}{l}\% \text { Difference } \\
\text { from } \Delta P=0^{\circ}\end{array}$ & $\begin{array}{l}\text { Average }^{\mathrm{b}} \\
(\mathrm{cm} / \mathrm{s})\end{array}$ & $\begin{array}{c}\mathrm{COV}^{\mathrm{b}} \\
(\%)\end{array}$ & $\begin{array}{l}\% \text { Difference } \\
\text { from } \Delta P=0^{\circ}\end{array}$ \\
\hline-0.8 & 0.320 & 3.9 & -1.3 & 1.478 & 3.5 & -1.3 \\
\hline-0.4 & 0.324 & 4.0 & -0.2 & 1.489 & 3.6 & -0.5 \\
\hline 0 & 0.324 & 3.8 & 0.0 & 1.497 & 3.8 & 0.0 \\
\hline 0.4 & 0.323 & 3.7 & -0.4 & 1.507 & 3.6 & 0.7 \\
\hline 0.8 & 0.326 & 4.0 & 0.6 & 1.541 & 4.4 & 3.0 \\
\hline
\end{tabular}

${ }^{a}$ Pressure differential across diffusion cell measured with impermeable membrane in place.

${ }^{\mathrm{b}}$ Average and coefficient of variation (COV) for five measurements of different paper areas.

${ }^{\mathrm{c}}$ Change in $D^{*}$ relative to the measurement at zero pressure differential.

estimated from the measurements using the following relationships (6). The diffusion coefficient is approximately ${ }^{1}$ related to the pore radius by

$$
D_{\mathrm{p}}=\frac{\pi D_{\mathrm{g}} x}{\ell} j r^{2}
$$

and diffusion capacity $\left(D^{*}\right)$ is defined as

$$
D^{*}=\frac{D_{p}}{x}
$$

where:

$D_{\mathrm{p}}=$ paper diffusion coefficient $\left(\mathrm{cm}^{2} / \mathrm{s}\right)$,

$D_{\mathrm{g}}=$ binary diffusion coefficient for $\mathrm{CO}_{2}$ into $\mathrm{N}_{2}(0.17$ $\mathrm{cm}^{2} / \mathrm{s}$ ),

$r=$ characteristic pore radius $(\mathrm{cm})$,

$j=$ number of pores of characteristic radius $r$ per $\mathrm{cm}^{2}$ of paper,

$x=$ the paper thickness $(\mathrm{cm})$, and

$\ell=$ the tortuous path length $(\mathrm{cm})$.

Paper permeability $\left(Z\right.$, in standard units of $\mathrm{cm}^{3} / \mathrm{min} / \mathrm{cm}^{2}$ at $100 \mathrm{mmH}_{2} \mathrm{O}$ pressure) is approximately (see footnote) related to the pore radius by

$$
Z=\frac{1.25 \times 10^{9}}{\ell} j r^{4} .
$$

\footnotetext{
${ }^{1}$ The diffusion coefficient and permeability are properly functions of the pore size distribution. It is assumed in Eqns. [1] and [3] that a characteristic pore number and radius may be used to approximate the pore size distribution. Application of Eqns. [1] and [3] assumes mass transport solely by molecular diffusion and viscous flow.
}

Combining Eqns. [2] and [3] gives the following approximation for the pore radius

$$
r=\sqrt{\frac{\pi D_{g} Z}{1.25 \times 10^{9} D^{*}}} .
$$

The permeability and diffusion capacity results, and the pore radius estimates from Eqn. [4] are summarized in Table 4. The estimated pore radii were linearly related to the specified values but the estimates were considerably higher. To make the estimated pore radii more closely match the specified values would require a 25 -fold increase in the diffusion capacity values shown in Table 4 . Since it is unlikely that the diffusion capacity measurement error is of that magnitude, it was concluded that Eqn. [4] does not accurately predict the pore radius for the filter membranes tested. The observation that the measured diffusion capacity values are systematically related to the pore sizes of filter membranes suggests that the measurements provide at least a relative indication of diffusion capacity.

Sensitivity of the diffusion capacity to small changes in the differential pressure across the diffusion cell was evaluated by making measurements with tubes of different length installed at the $\mathrm{CO}_{2}$ chamber outlet. Measurements were made for papers of low $(5 \mathrm{~cm} / \mathrm{min})$ and high $(50 \mathrm{~cm} / \mathrm{min})$ permeability with each of five different tube lengths. The pressure differential was measured for each tube length while an impermeable plastic membrane was clamped in the diffusion cell. The results of this experiment (Table 5) show small changes in the diffusion capacity for cell differential pressure ranging from +0.8 to $-0.8 \mathrm{mmH}_{2} \mathrm{O}$. For the high permeability paper, the diffusion capacity decreased by $1.3 \%$ and increased by $3 \%$ at the differential 
Table 6. Effect of flow rate on diffusion capacity measurements for papers of low and high permeability

\begin{tabular}{|c|c|c|c|c|c|c|}
\hline \multirow[b]{2}{*}{$\begin{array}{l}\text { Flow rate }^{a} \\
\left(\mathrm{~cm}^{3} / \mathrm{min}\right)\end{array}$} & \multicolumn{3}{|c|}{ Low permeability paper $D^{\star}$} & \multicolumn{3}{|c|}{ High permeability paper $D^{*}$} \\
\hline & $\begin{array}{l}\text { Regression }^{\mathrm{b}} \\
(\mathrm{cm} / \mathrm{s})\end{array}$ & $\begin{array}{c}\text { Numerical }^{\mathrm{c}} \\
(\mathrm{cm} / \mathrm{s})\end{array}$ & $\begin{array}{l}\% \text { Difference from } \\
\text { flow }=550 \mathrm{~cm}^{3} / \mathrm{min}^{d}\end{array}$ & $\begin{array}{l}\text { Regression }^{\mathrm{b}} \\
(\mathrm{cm} / \mathrm{s})\end{array}$ & $\begin{array}{c}\text { Numerical }^{\mathrm{c}} \\
(\mathrm{cm} / \mathrm{s})\end{array}$ & $\begin{array}{l}\% \text { Difference from } \\
\text { flow }=550 \mathrm{~cm}^{3} / \mathrm{min}^{d}\end{array}$ \\
\hline 330 & 0.343 & 0.324 & 5.5 & 2.122 & 1.476 & 40.6 \\
\hline 439 & 0.332 & 0.323 & 1.9 & 1.710 & 1.500 & 13.3 \\
\hline 550 & 0.325 & 0.322 & 0.0 & 1.509 & 1.501 & 0.0 \\
\hline 659 & 0.324 & 0.322 & -0.5 & 1.423 & 1.520 & -5.7 \\
\hline 770 & 0.324 & 0.324 & -0.4 & 1.395 & 1.556 & -7.6 \\
\hline
\end{tabular}

${ }^{a}$ Flow rate of $\mathrm{CO}_{2}$ and $\mathrm{N}_{2}$ through the diffusion cell at ambient barometric pressure and temperature.

${ }^{\mathrm{b}}$ Average for five measurements of different paper areas calculated with the regression equation.

${ }^{c}$ Average for five measurements of different paper areas calculated with the numerical model (8).

${ }^{d}$ Change in diffusion capacity as calculated with the regression equation relative to $550 \mathrm{~cm}^{3} / \mathrm{min}$ flow.

Table 7. Effect of $\mathrm{CO}_{2}, \mathrm{~N}_{2}$ and vacuum flow variation on diffusion capacity measurements for papers of low and high permeability

\begin{tabular}{|c|c|c|c|c|c|c|}
\hline \multirow{2}{*}{\multicolumn{3}{|c|}{ Flow rate $\left(\mathrm{cm}^{3} / \mathrm{min}\right)^{\mathrm{a}}$}} & \multicolumn{2}{|c|}{ Low permeability paper $D^{\star}$} & \multicolumn{2}{|c|}{ High permeability paper $D^{*}$} \\
\hline & & & \multirow{2}{*}{$\begin{array}{l}\text { Average }^{b} \\
(\mathrm{~cm} / \mathrm{s})\end{array}$} & \multirow{2}{*}{$\begin{array}{l}\% \text { Difference from } \\
\text { flow }=552 \mathrm{~cm}^{3} / \mathrm{min}^{\mathrm{c}}\end{array}$} & \multirow{2}{*}{$\begin{array}{c}\text { Average }^{b} \\
(\mathrm{~cm} / \mathrm{s})\end{array}$} & \multirow{2}{*}{$\begin{array}{l}\% \text { Difference from } \\
\text { flow }=552 \mathrm{~cm}^{3} / \mathrm{min}^{c}\end{array}$} \\
\hline $\mathrm{N}_{2}$ & $\mathrm{CO}_{2}$ & Vacuum & & & & \\
\hline 552 & 497 & 221 & 0.329 & 1.0 & 1.468 & -2.3 \\
\hline 552 & 525 & 221 & 0.326 & 0.2 & 1.484 & -1.2 \\
\hline 552 & 552 & 221 & 0.326 & 0.0 & 1.502 & 0.0 \\
\hline 552 & 580 & 221 & 0.326 & 0.2 & 1.533 & 2.1 \\
\hline 552 & 607 & 221 & 0.331 & 1.6 & 1.556 & 3.6 \\
\hline 497 & 552 & 221 & 0.366 & 12.3 & 1.819 & 21.2 \\
\hline 525 & 552 & 221 & 0.346 & 6.3 & 1.648 & 9.7 \\
\hline 552 & 552 & 221 & 0.326 & 0.0 & 1.502 & 0.0 \\
\hline 580 & 552 & 221 & 0.309 & -5.0 & 1.392 & -7.3 \\
\hline 607 & 552 & 221 & 0.295 & -9.5 & 1.296 & -13.7 \\
\hline 552 & 552 & 166 & 0.328 & 0.8 & 1.518 & 1.1 \\
\hline 552 & 552 & 221 & 0.326 & 0.0 & 1.502 & 0.0 \\
\hline 552 & 552 & 277 & 0.330 & 1.5 & 1.506 & 0.3 \\
\hline
\end{tabular}

${ }^{a}$ Flow rate of $\mathrm{N}_{2}$ and $\mathrm{CO}_{2}$ through the diffusion cell, and flow through the analyzer sample loop (vacuum) at ambient barometric pressure and temperature.

${ }^{b}$ Average for five measurements of different paper areas calculated with the regression equation assuming constant $\mathrm{N}_{2}$ and $\mathrm{CO}_{2}$ flow of $552 \mathrm{~cm}^{3} / \mathrm{min}$

${ }^{\circ}$ Change in diffusion capacity as calculated with the regression equation relative to $552 \mathrm{~cm}^{3} / \mathrm{min}$ flow.

pressure extremes tested. In normal operation of the apparatus, the differential pressure is typically between -0.1 to $0.1 \mathrm{mmH}_{2} \mathrm{O}$ with an impermeable plastic film in the cell. During sample testing, the differential pressure is typically between -0.5 and $0.5 \mathrm{mmH}_{2} \mathrm{O}$.

The diffusion capacity of paper is expected to be independent of the gas flow rate through the diffusion cell. Measurements were made for papers of low $(5 \mathrm{~cm} / \mathrm{min})$ and high $(50$ $\mathrm{cm} / \mathrm{min}$ ) permeability at flow rates ranging from 300 to 700 SCCM. Diffusion capacity calculated with the numerical model described by DRAKE (8) showed little variation with gas flow rate. However, the diffusion capacity values calculated with the regression model showed appreciable flow rate dependence (Table 6). The flow rate routinely used in the apparatus is 500 SCCM, and the flow at ambient conditions ranges from about 547 to about $567 \mathrm{~cm}^{3} / \mathrm{min}$ (about $\pm 2 \%$ of the flow rate at the average ambient conditions). Analysis of the data in Table 6 showed that flow rate changes of $\pm 2 \%$ from the target value resulted in changes to diffusion capacity calculated with the regression model of less than $1 \%$. These results demonstrate that the flow rate normalization used with the regression model provides adequate diffusion capacity estimates for the limited flow rate range observed due to fluctuations in ambient conditions.

Effects of independently changing the $\mathrm{CO}_{2}, \mathrm{~N}_{2}$ and vacuum flow (analyzer sample loop) flow rates were evaluated for papers of low and high permeability. In this experiment, one of the flow rates was varied while the others were held constant at the standard values (500 SCCM for $\mathrm{CO}_{2}$ and $\mathrm{N}_{2} ; 200$ SCCM for the vacuum flow). Diffusion capacity values were calculated with the regression model, and were not corrected for the experimental changes to the flow rates. Results from this experiment (Table 7) revealed that the diffusion capacity values were relatively insensitive to variation in the $\mathrm{CO}_{2}$ or vacuum flow rates, but highly sensitive to $\mathrm{N}_{2}$ flow changes. These results demonstrate that precision control of the gas flows, and appropriate accounting for flow effects are required for obtaining good data from the apparatus. 
Table 8. Diffusion capacity and permeability for conventional cigarette papers

\begin{tabular}{|c|c|c|c|c|c|c|}
\hline \multirow[b]{2}{*}{$\begin{array}{l}\text { Paper thickness } \\
(\mathrm{mm})\end{array}$} & \multicolumn{2}{|c|}{ Permeability $^{a}$} & \multicolumn{2}{|c|}{$D^{\star \mathrm{b}}$} & \multirow[b]{2}{*}{$\begin{array}{c}D_{p_{p}}{ }^{c} \\
\left(\mathrm{~cm}^{2} / \mathrm{s}\right)\end{array}$} & \multirow[b]{2}{*}{$\begin{array}{l}\text { Pore radius }{ }^{d} \\
\quad(\mathrm{~mm})\end{array}$} \\
\hline & $\begin{array}{l}\text { Average } \\
(\mathrm{cm} / \mathrm{min})\end{array}$ & $\begin{array}{l}\text { COV } \\
(\%)\end{array}$ & $\begin{array}{c}\text { Average } \\
(\mathrm{cm} / \mathrm{s})\end{array}$ & $\begin{array}{l}\text { COV } \\
(\%)\end{array}$ & & \\
\hline 37 & 5.9 & 5.6 & 0.333 & 2.4 & $1.222 \mathrm{E}-03$ & 0.87 \\
\hline 37 & 6.4 & 13.8 & 0.328 & 2.3 & $1.221 \mathrm{E}-03$ & 0.91 \\
\hline 38 & 7.2 & 10.7 & 0.408 & 0.9 & $1.546 \mathrm{E}-03$ & 0.87 \\
\hline 39 & 12.6 & 2.1 & 0.848 & 2.4 & $3.331 E-03$ & 0.80 \\
\hline 37 & 19.5 & 5.2 & 1.037 & 1.7 & $3.805 \mathrm{E}-03$ & 0.90 \\
\hline 39 & 21.6 & 6.4 & 1.110 & 2.0 & $4.339 \mathrm{E}-03$ & 0.91 \\
\hline 39 & 27.3 & 1.3 & 1.230 & 2.0 & $4.810 \mathrm{E}-03$ & 0.97 \\
\hline 39 & 29.2 & 4.5 & 1.298 & 2.7 & $5.061 \mathrm{E}-03$ & 0.98 \\
\hline 39 & 35.7 & 7.1 & 1.459 & 4.6 & $5.645 \mathrm{E}-03$ & 1.02 \\
\hline 40 & 37.6 & 3.5 & 1.231 & 1.3 & 4.937E-03 & 1.14 \\
\hline 39 & 43.7 & 7.7 & 1.277 & 2.1 & $4.980 \mathrm{E}-03$ & 1.21 \\
\hline 40 & 45.3 & 10.6 & 1.511 & 2.1 & $6.045 \mathrm{E}-03$ & 1.13 \\
\hline 40 & 50.0 & 12.7 & 1.343 & 3.6 & $5.359 \mathrm{E}-03$ & 1.26 \\
\hline 40 & 58.1 & 4.5 & 1.489 & 1.5 & $6.016 \mathrm{E}-03$ & 1.29 \\
\hline 41 & 61.7 & 9.3 & 1.487 & 1.0 & $6.038 \mathrm{E}-03$ & 1.33 \\
\hline
\end{tabular}

a Permeability measured according to the CORESTA protocol. Average and COV for ten measurements.

${ }^{b}$ Diffusion capacity average and COV for five measurements.

${ }^{c} D_{\mathrm{p}}=D^{*}$ multiplied by the paper thickness in $\mathrm{cm}$.

${ }^{\mathrm{d}}$ Estimated from experimental values for $D^{*}$ and permeability using Eqn. [4].

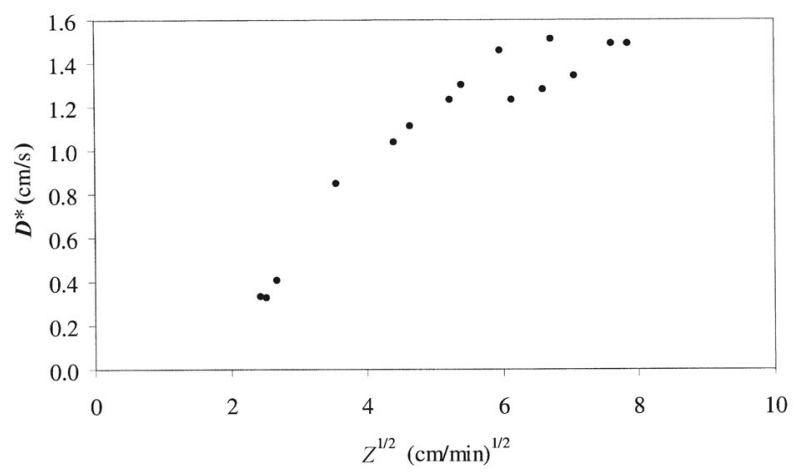

Figure 3. Relationship between permeability $(Z)$ and diffusion capacity $\left(D^{\star}\right)$ for conventional cigarette papers

\section{Evaluation of conventional cigarette paper}

The relationship between permeability $(Z)$ and $D^{*}$ was investigated by measuring diffusion capacity for papers of permeability ranging from $6 \mathrm{~cm} / \mathrm{min}$ to $62 \mathrm{~cm} / \mathrm{min}$. These results are summarized in Table 8 . A plot of the diffusion capacity against the square-root of the permeability data from Table 8 (Figure 3) shows an approximately linear relationship similar to that found by BAKER (6) for $\mathrm{CO}$ diffusion coefficients. Note that Eqn. [4] indicates a linear relationship between $Z$ and $D^{*}$ for papers of the same pore radius. The observed non-linear relationship between $Z$ and $D^{*}$ could be a consequence of varying pore sizes of the papers tested. Pore radius estimates made from the data in Table 8 using Eqn. [4] ranged from 0.80 to $1.33 \mu \mathrm{m}$ (average was $1.05 \mu \mathrm{m})$.

BAKER (6) reported a $D_{\mathrm{p}}$ value for CO of $4.5 \times 10^{-3} \mathrm{~cm}^{2} / \mathrm{s}$ for paper of $10 \mathrm{~cm} / \mathrm{min}$ permeability. In the present work, a $D_{\mathrm{p}}$ value for $\mathrm{CO}_{2}$ of $3.3 \times 10^{-3} \mathrm{~cm}^{2} / \mathrm{s}$ was observed for a paper of $12.6 \mathrm{~cm} / \mathrm{min}$ permeability (Table 8 ). For identical
Table 9. Comparison of diffusion coefficients from this work with data of MIURA

\begin{tabular}{l|c|c|c}
\hline \multicolumn{2}{c|}{ This work $^{\mathrm{a}}$} & \multicolumn{2}{c}{ From reference (9) } \\
\hline $\begin{array}{l}\text { Permeability } \\
\text { (cm/min) }\end{array}$ & $\begin{array}{c}D_{\mathrm{p}} \\
\left(\mathrm{cm}^{2} / \mathrm{s}\right)\end{array}$ & $\begin{array}{c}\text { Permeability } \\
(\mathrm{cm} / \mathrm{min})\end{array}$ & $\begin{array}{c}D_{\mathrm{p}}{ }^{\mathrm{b}} \\
\left(\mathrm{cm}^{2} / \mathrm{s}\right)\end{array}$ \\
\hline 6.4 & $1.221 \mathrm{E}-03$ & 6 & $1.80 \mathrm{E}-03$ \\
7.2 & $1.546 \mathrm{E}-03$ & 7 & $1.20 \mathrm{E}-03$ \\
19.5 & $3.805 \mathrm{E}-03$ & 19 & $3.30 \mathrm{E}-03$ \\
27.3 & $4.810 \mathrm{E}-03$ & 25 & $1.80 \mathrm{E}-03$ \\
\hline
\end{tabular}

${ }^{a}$ Data from Table 8 for papers of permeability equivalent to those from reference 9 .

${ }^{\mathrm{b}}$ Oxygen diffusion coefficient.

papers, the $D_{\mathrm{p}}$ value for $\mathrm{CO}$ should be about $23 \%$ higher than that for $\mathrm{CO}_{2}$ (the ratio of $D_{\mathrm{g}}$ values for $\mathrm{CO}$ and $\mathrm{CO}_{2}$ is 1.23). These results appear to show reasonable agreement after accounting for the expected reduction in the $D_{\mathrm{p}}$ value due to the difference in diffusing gas. MIURA (9) reported $D_{\mathrm{p}}$ values for oxygen diffusion through papers of permeability ranging from 2 to $25 \mathrm{~cm} / \mathrm{min}$. The results of MIURA are compared with observations for papers of similar permeability in Table 9. With the exception of the $25 \mathrm{~cm} / \mathrm{min}$ paper, this comparison indicates reasonable agreement with the data of MIURA. However, the $D_{\mathrm{p}}$ values for $\mathrm{O}_{2}$ diffusion should be higher than the $\mathrm{CO}_{2}$ values $\left(D_{\mathrm{g}}\right.$ for $\mathrm{O}_{2}$ diffusion into $\mathrm{N}_{2}$ is greater than that for $\mathrm{CO}_{2}$ ). The $D_{\mathrm{p}}$ values for $\mathrm{CO}_{2}$ exceeded the $\mathrm{O}_{2}$ values for three of the four observations compared.

The diffusion capacity data shown in Table 8 are averages of five measurements taken along a $1 \mathrm{~m}$ strip of paper, while the permeability data are averages of ten measurements. The within-strip COV for the diffusion capacity data was much lower (average $=2.2 \%$ ) than that of the permeability data (average $=7.0 \%$ ). This suggests that the 
Table 10. Diffusion capacity and permeability measurements for electrostatically perforated cigarette papers (pore radius estimated from experimental values for $D^{\star}$ and permeability using Eqn. [4] )

\begin{tabular}{lcc|c}
\hline Perforation & $\begin{array}{c}\text { Permeability } \\
(\mathrm{cm} / \mathrm{min})\end{array}$ & $\begin{array}{c}D^{\star} \\
(\mathrm{cm} / \mathrm{s})\end{array}$ & $\begin{array}{c}\text { Pore radius } \\
(\mu \mathrm{m})\end{array}$ \\
\hline no & 40.6 & 1.191 & 1.21 \\
yes & 82.3 & 1.279 & 1.66 \\
yes & 155.2 & 1.317 & 2.24 \\
yes & 235.0 & 1.261 & 2.82 \\
\hline
\end{tabular}

Table 11. Diffusion capacity and permeability measurements for print-banded cigarette papers

\begin{tabular}{|c|c|c|c|c|}
\hline \multicolumn{2}{|c|}{ Permeability $^{a}$} & \multicolumn{2}{|c|}{$D^{* \mathrm{~b}}$} & \multirow[b]{2}{*}{$\begin{array}{c}\text { Pore radius }{ }^{\circ} \\
(\mu \mathrm{m})\end{array}$} \\
\hline $\begin{array}{l}\text { Average } \\
(\mathrm{cm} / \mathrm{min})\end{array}$ & $\begin{array}{c}\text { COV } \\
(\%)\end{array}$ & $\begin{array}{l}\text { Average } \\
(\mathrm{cm} / \mathrm{min})\end{array}$ & $\begin{array}{c}\text { COV } \\
(\%)\end{array}$ & \\
\hline \multicolumn{5}{|c|}{ Within-band ${ }^{d}$} \\
\hline 6.1 & 13.6 & 0.056 & 8.8 & 2.16 \\
\hline 7.5 & 17.1 & 0.075 & 4.4 & 2.07 \\
\hline 8.6 & 21.3 & 0.099 & 6.6 & 1.93 \\
\hline 9.6 & 19.9 & 0.146 & 2.1 & 1.68 \\
\hline 11.0 & 31.9 & 0.164 & 4.1 & 1.69 \\
\hline 12.3 & 34.6 & 0.052 & 11.7 & 3.18 \\
\hline 13.6 & 66.5 & 0.060 & 17.3 & 3.11 \\
\hline 17.0 & 35.2 & 0.177 & 5.9 & 2.03 \\
\hline 19.1 & 50.0 & 0.083 & 7.8 & 3.14 \\
\hline 23.9 & 26.6 & 0.200 & 5.8 & 2.26 \\
\hline 26.7 & 37.1 & 0.189 & 10.0 & 2.46 \\
\hline \multicolumn{5}{|c|}{ Between band ${ }^{e}$} \\
\hline 44.3 & 7.2 & 1.660 & 2.2 & 1.07 \\
\hline 44.9 & 5.1 & 1.584 & 5.2 & 1.10 \\
\hline 42.9 & 5.8 & 1.599 & 2.8 & 1.07 \\
\hline 41.6 & 7.5 & 1.600 & 2.3 & 1.05 \\
\hline 43.4 & 7.8 & 1.549 & 2.5 & 1.09 \\
\hline 50.8 & 11.9 & 1.690 & 5.3 & 1.13 \\
\hline 56.3 & 17.4 & 1.714 & 3.8 & 1.18 \\
\hline 52.4 & 12.6 & 1.702 & 4.0 & 1.15 \\
\hline 59.0 & 18.8 & 1.724 & 4.3 & 1.21 \\
\hline 59.9 & 17.4 & 1.652 & 6.1 & 1.24 \\
\hline 52.1 & 14.5 & 1.706 & 3.8 & 1.14 \\
\hline
\end{tabular}

${ }^{\text {a }}$ Permeability measured according to the CORESTA protocol. Average and COV for ten measurements.

${ }^{\mathrm{b}}$ Diffusion capacity average and COV for five measurements.

${ }^{\circ}$ Estimated from experimental values for $D^{*}$ and permeability using Eqn. [4].

${ }^{d}$ Measurements made within the $6 \mathrm{~mm}$ wide banded area of the paper.

${ }^{\mathrm{e}}$ Measurements made in the paper area between the bands.

diffusion capacity can be measured with greater precision than permeability. A sound explanation has not been developed for the observed difference between variability of the diffusion capacity and permeability measurements. However, preliminary experiments suggest that the higher permeability variance is not due to leakage at the test head.

\section{Effect of electrostatic perforation on the diffusion capacity}

Electrostatic perforations can substantially increase cigarette paper permeability due to introduction of a small number of relatively large holes in the paper. Eqns. [2] and

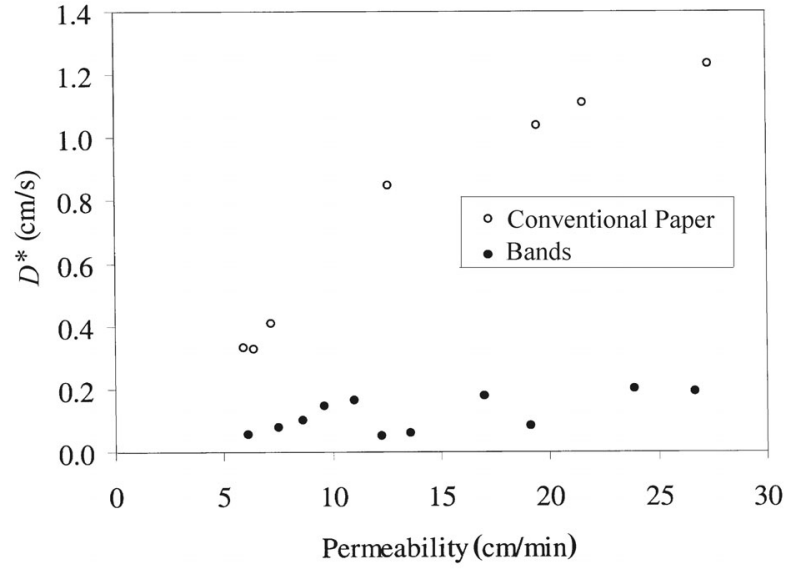

Figure 4. Relationship between permeability $(Z)$ and diffusion capacity $\left(D^{\star}\right)$ for printed bands and for conventional cigarette papers

[3] indicate that increasing the pore radius by perforation results in a permeability increase that is greater than the increase in the diffusion capacity. The effect of perforation was examined by measuring diffusion capacity for a paper of $40 \mathrm{~cm} / \mathrm{min}$ permeability and for the same paper perforated to obtain permeability ranging from 82 to 235 $\mathrm{cm} / \mathrm{min}$. These results are summarized in Table 10. Measured $D^{*}$ values for the perforated papers increased by 6 $11 \%$ relative to the $D^{*}$ value for the base paper. Pore radius estimates from Eqn. [4] increased substantially with perforation. The minimal change in diffusion capacity due to perforation is in agreement with the observations reported by BAKER (6). These results confirm that the diffusion capacity is governed by small pores in the paper structure. On the basis of this experiment, it may also be reasonably surmised that the diffusion capacity is similarly insensitive to pinholes in the paper. Because diffusion of oxygen through the paper is likely to govern cigarette burn rate, the diffusion capacity is hypothesized to be a better indicator of burn rate than permeability of papers with pinholes or perforations.

\section{Diffusion capacity for banded papers}

Diffusion capacity and permeability measurements for banded papers are summarized in Table 11. The diffusion capacity and permeability values for the bands were considerably lower than those for the unprinted areas of the paper between the bands. Comparison of the data in Table 11 with the results for conventional papers shown in Table 8 reveals that the band diffusion capacity is lower than the diffusion capacity of unprinted paper of the same permeability (Figure 4). This observation suggests that the band material preferentially occludes the smaller pores in the paper. Pore radius estimates (Eqn. [4]) indicate that the within-band pore size is about twice that of the unprinted paper (Table 11), suggesting that only relatively large pores remain in the banded areas. As a consequence, printed papers may show different performance characteristics on finished cigarettes than unprinted papers of the same permeability. For example, if cigarette burn rates are governed by diffusion through the paper, within-band burn rates would be expected to be lower than those for un- 
printed paper of the same permeability. Also, outward diffusion of gases formed during smoking (i.e., $\mathrm{CO}$ ) could be hindered to a greater extent within bands.

As mentioned above, the COV values for the diffusion capacity data shown in Table 11 were lower than those for the permeability data. For bands, the diffusion capacity COV averaged $7.7 \%$ while the band permeability COV averaged $32.2 \%$. For the unprinted paper, the diffusion capacity COV averaged $3.8 \%$ and the permeability COV averaged $11.5 \%$. Although the bands are more variable than the unprinted paper, the diffusion capacity consistently shows much less variability than the permeability.

\section{CONCLUSIONS}

An apparatus was developed that is capable of measuring gas diffusion through cigarette paper and is suitable for testing printed bands. Although it was not possible to verify the absolute accuracy of the measured diffusion coefficients, the results appear to show fairly good agreement with published data. Repeatability and reproducibility of the diffusion capacity measurements are excellent. Variability of the diffusion capacity is consistently lower than that of permeability. Accordingly, the diffusion capacity measurement appears particularly useful for quality assurance purposes.

A survey of conventional cigarette papers indicated that the permeability and diffusion capacity are related as expected from theoretical considerations. Perforations in the paper caused only small changes to the diffusion capacity, confirming that diffusion is governed by relatively small pores in the paper. Banded papers of equivalent permeability to conventional paper showed lower diffusion capacity, suggesting that the band material occludes the smaller pores in the paper. Diffusion capacity data can provide useful information in addition to that provided by routine permeability tests. Because the diffusion capacity is relatively insensitive to larger pores in the paper, it can be used to distinguish papers of equivalent permeability that may show burn rate and smoke yield differences in finished cigarettes. Permeability and diffusion capacity data can be used to estimate relative pore sizes of papers.

\section{ACKNOWLEDGMENT}

The authors gratefully acknowledge Dr. Stephen B. Sears for his helpful discussions and guidance in the final preparation of this manuscript.

\section{REFERENCES}

1. Branton, P.J.: Methods for the structural characterisation of cigarette paper; Presented at the $56^{\text {th }}$ Tobacco Science Research Conference, Lexington, KY, Sept 29-Oct 2, 2002, Program Booklet and Abstracts Vol. 56, No. 52, p. 51.
2. NYCRR Title 19 Part 429: Fire safety standards for cigarettes; New York Code Rules and Regulations, April 21, 2004.

3. ASTM E 2187-02b: Standard method for measuring the ignition strength of cigarettes; American Society for Testing and Materials, ASTM Int., 2002.

4. Durocher, D.F. and T. Kraker: The role of banded cigarette paper in reduced ignition propensity cigarettes; Presented at the $57^{\text {th }}$ Tobacco Science Research Conference, Norfolk, VA, Sept 21-24, 2003, Program Booklet and Abstracts Vol. 57, No. 26, p. 34.

5. Codwise, W.R. and D.F. Durocher: Techniques for making accurate low permeability measurements on print banded papers using the Borgwaldt A-10; Presented at the $58^{\text {th }}$ Tobacco Science Research Conference, Winston-Salem, NC, Sept 19-22, 2004, Program Booklet and Abstracts Vol. 58, No. 69, p. 64.

6. Baker, R.R. and R.A. Crellin: The diffusion of carbon monoxide out of cigarettes; Beitr. Tabakforsch. 9 (1977) 131-140.

7. Muramatsu, M., T. Mikami, N. Naito, and H. Tomita: A model study on the diffusion and the dilution of low molecular weight gaseous components through cigarette paper during smoking; Beitr. Tabakforsch. 9 (1977) 141-146.

8. Drake, D.G., D.S. Riley, R.R. Baker, and K.D. Kilburn: On a cell to measure diffusion coefficients of gases through cigarette papers; Int. J. Heat Mass Transfer 23 (1980) 127-134.

9. Miura, K: Oxygen diffusion through cigarette paper; Beitr. Tabakforsch. Int. 19 (2001) 205-208.

10. Durocher, D.F.: Wrapper constructions for selfextinguishing smoking articles; United States Patent 4615345, Oct. 7, 1986.

11. Eitzinger, B.: Design guidelines for papers for low ignition propensity cigarettes; Presented at the 2004 CORESTA Congress, Kyoto, Japan.

12. Washburn, E.W. (Ed.): International critical tables of numerical data, Physics, Chemistry and Technology, McGraw-Hill, NY, Vol. V, 1929, p. 62.

\section{Corresponding author:}

Alan B. Norman

Senior Principal Scientist

Research and Development

$R$. J. Reynolds Tobacco Company

Bowman Gray Technical Center

950 Reynolds Blvd

Winston-Salem, NC 27102

e-mail:normana@rjrt.com 